\title{
New Sources of Adult Plant and Seedling Resistance to Puccinia coronata f. sp. avenae Identified among Avena sativa Accessions From the National Small Grains Collection
}

\author{
Belayneh Admassu-Yimer, ${ }^{\dagger}$ Oak Ridge Institute for Science and Education Research Participant, Oak Ridge, TN 37831; Tyler Gordon, \\ United States Department of Agriculture-Agricultural Research Service (USDA-ARS), Small Grains and Potato Germplasm Research, Aber- \\ deen, ID 83210; Stephen Harrison, Louisiana State University AgCenter-SPESS, Baton Rouge 70803-2110; Shahryar Kianian, USDA-ARS \\ Cereal Disease Laboratory, St. Paul, MN 55108; and Harold Bockelman, J. Michael Bonman, and Kathy Esvelt Klos, USDA-ARS, Small \\ Grains and Potato Germplasm Research, Aberdeen, ID 83210
}

\begin{abstract}
Accessions of cultivated oat (Avena sativa L.) from the United States Department of Agriculture-Agricultural Research Service Small Grains Collection in Aberdeen, ID were characterized for adult plant resistance (APR) and seedling resistance to crown rust, caused by Puccinia coronata f. sp. avenae. Initially, 607 oat accessions with diverse geographic origins were evaluated in field tests in Baton Rouge, LA. Of those, $97 \mathrm{ac}-$ cessions were not fully susceptible and were tested in the field in St. Paul, MN against a diverse $P$. coronata $\mathrm{f}$. sp. avenae population. Thirty-six accessions that had some level of resistance in both field tests and mean coefficients of infection of $\leq 20$ were further evaluated for APR and seedling resistance. Among these, four accessions (PI 193040, PI 194201, PI 237090, and PI 247930) were resistant to eight $P$. coronata

f. sp. avenae races as seedlings. Twenty-nine accessions had resistance to at least one of the $P$. coronata $\mathrm{f}$. $\mathrm{sp}$. avenae races. Three accessions (CIav 2272, CIav 3390, and PI 285583) were fully susceptible to all eight $P$. coronata f. sp. avenae races as seedlings. Further evaluation of the three seedling-susceptible accessions at the flag leaf stage in a growth chamber resulted in moderately susceptible to moderately resistant responses. The resistance sources presented here may contain genes not deployed in elite oat varieties, and may be useful for future crown rust resistance breeding. The adult and seedling resistance found in accessions of the cultivated oat species is especially valuable because it avoids problems associated with the transfer of genes from wild species to cultivated oat.
\end{abstract}

Cultivated oat (Avena sativa $\mathrm{L}$.) is an important cereal grown as a dual-purpose crop (forage and grain), mainly in Australia, North America, and Europe. In many environments where oat is cultivated, crown rust disease, caused by Puccinia coronata f. sp. avenae P. Syd. $\&$ Syd., is the main limiting factor for production (Carson 2011). Estimates of significant yield reduction include $\$ 16$ million over a 5year period (2001 to 2005) in Canada (McCallum et al. 2007) and between 1.7 and $20 \%$ of oat production in the United States (Carson 2011). Host resistance is the most effective and economically viable method of crown rust control. Over 100 race-specific genes for crown rust resistance have been identified in oat. Unfortunately, the emergence of new races in populations of $P$. coronata $\mathrm{f}$. sp. avenae is continuous and rapid as the pathogen undergoes sexual recombination on the alternate host, buckthorn (Rhamnus carthartica L.) (Carson 2011). As a result, the effectiveness of newly deployed seedling resistance genes is often short-lived in North America (i.e., 5 years or less) (Carson 2011; Chong and Kolmer 1993; Leonard et al. 2004). Many seedling resistance genes such as $P c 38, P c 39, P c 48$, and Pc68 have lost their effectiveness over time (McCallum et al.

${ }^{\dagger}$ Corresponding author: Belayneh Admassu-Yimer;

E-mail: belayneh.yimer@ars.usda.gov

Funding: This research was supported, in part, by an appointment of B. Admassu-Yimer to the ARS Research Participation Program administered by the Oak Ridge Institute for Science and Education (ORISE) through an interagency agreement between the U.S. Department of Energy (DOE) and the USDA. ORISE is managed by Oak Ridge Associated Universities (ORAU) under DOE contract number DE-SC0014664.

All opinions expressed in this article are those of the authors and do not necessarily reflect the policies and views of USDA, ARS, DOE, or ORAU/ ORISE.

Accepted for publication 25 May 2018.

C 2018 The American Phytopathological Society
2007). Adult plant resistance (APR), where the plant is susceptible at the seedling stage but resistant at the reproductive stage, is an alternative to seedling resistance and may improve the durability of resistance in cereals to rust diseases (Basnet et al. 2013). The effectiveness and durability of APR has been demonstrated in various cereal-rust pathosystems (Basnet et al. 2013; McIntosh et al. 1995; Milus et al. 2015). Combining APR with seedling resistance would provide protection throughout the growing season, and pyramiding multiple APR and seedling resistance types has potential to provide greater durability of resistance than deployment of either resistance type alone (Bariana et al. 2007; Sandhu et al. 2014).

Only a few quantitative trait loci that confer APR to crown rust in oat have been described (Acevedo et al. 2010; Babiker et al. 2015; Cabral et al. 2011; Klos et al. 2017; Lin et al. 2014; Portyanko et al. 2005). Hence, there is a need to identify new sources of resistance to counter the ever-evolving virulence of the oat crown rust pathogen.

The United States Department of Agriculture (USDA) National Small Grains Collection (NSGC) in Aberdeen, ID currently holds over 21,000 accessions of Avena spp. that were collected worldwide since the 1920s (Germplasm Resources Information Network [GRIN]; https://www.ars-grin.gov/npgs/). Systematic testing of the collection for crown rust resistance was carried out in the early 1980s in Ames, IA and in the 1990s in St. Paul, MN. Since then, only sporadic attempts have been made to test NSGC accessions for crown rust resistance, with the main focus on wild relatives of oat (Cabral and Park 2014; Carson 2009; Tan and Carson 2013). There are nearly 4,000 Avena spp. accessions in the NSGC that have not yet been tested for resistance to crown rust, some of which may contain novel genes for adult plant and seedling resistance. The objective of this study was to assess field resistance to crown rust in a diverse set of A. sativa accessions and to characterize the level and pattern of seedling resistance and APR in selected accessions.

\section{Materials and Methods}

Plant and pathogen materials. In total, 607 A. sativa accessions originating from 44 countries (Table 1) were obtained from the 
NSGC and evaluated for field and seedling resistance to crown rust. The accessions were randomly chosen from among all the accessions, with a bias toward those that had no crown rust resistance evaluations on record. Accessions that previously had not been evaluated

Table 1. Geographic origin of Avena sativa accessions and their infection response under field conditions in Baton Rouge in 2016

\begin{tabular}{lcrrrrc}
\hline & \multicolumn{5}{c}{ Infection response $^{\mathbf{x}}$} \\
\cline { 2 - 5 } \multicolumn{1}{c}{ Origin } & Tested $(\boldsymbol{n})$ & \multicolumn{1}{c}{$\mathbf{S}$} & MS & MR & $\mathbf{R}$ & Some resistance $(\boldsymbol{\%})^{\mathbf{z}}$ \\
\hline Europe & 418 & 387 & 15 & 10 & 6 & 7.4 \\
North America & 86 & 67 & 4 & 12 & 3 & 22.1 \\
Asia & 23 & 20 & 1 & 2 & 0 & 13 \\
South America & 44 & 10 & 14 & 10 & 10 & 77.3 \\
Africa & 19 & 17 & 0 & 1 & 1 & 10.5 \\
Australia & 17 & 9 & 3 & 3 & 2 & 47.1 \\
Total & 607 & 510 & 37 & 38 & 22 & 16 \\
\hline
\end{tabular}

${ }^{x}$ Abbreviations: $\mathrm{S}=$ susceptible, $\mathrm{MS}=$ moderately susceptible, $\mathrm{MR}=$ moderately resistant, and $\mathrm{R}=$ resistant.

y Number of accessions tested.

${ }^{\mathrm{z}}$ Percentage of accessions with some level of disease resistance, with infection responses including MS, MR, or R. comprised $63 \%$ of the sample. The accessions were classified as cultivars $(48 \%)$ or landraces $(30 \%)$, or had uncertain improvement status $(22 \%)$

Eight $P$. coronata f. sp. avenae races-three from the USDA Agricultural Research Service (ARS) Small Grains and Potato Germplasm Research Unit, Aberdeen, ID and five from the USDA-ARS Cereal Disease Laboratory, St. Paul, MN—were sourced for seedling tests.

Evaluation of accessions for field resistance. The 607 oat accessions, along with the susceptible check cultivar Otana and the resistant check cultivar TAM-O-301 carrying the Pc58 seedling resistance gene complex, were planted at the Louisiana State University experiment station in Baton Rouge, LA in November 2015. Each accession was planted in a nonreplicated head row. The susceptible and resistant checks were planted every 40 rows. Natural $P$. coronata $\mathrm{f}$. sp. avenae infection occurred and crown rust was rated twice in March and April 2016, first at the booting stage and then when most plants were at the flag leaf stage. Disease severity was measured from 0 to $100 \%$ based on the modified Cobb scale (Peterson et al. 1948). Infection response was recorded as resistant, with necrotic flecks $(\mathrm{R})$; moderately resistant, with small uredinia surrounded by necrosis or chlorosis (MR); moderately susceptible, with medium to large uredinia surrounded by chlorosis (MS); and susceptible, with large

Table 2. Reaction of 36 oat accessions to crown rust under natural infection in the field as adult plants in Baton Rouge (BR) LA and St. Paul (SP) MN in 2016 and 2017

\begin{tabular}{|c|c|c|c|c|c|c|c|c|}
\hline \multirow[b]{2}{*}{ Accession } & \multirow[b]{2}{*}{ Origin } & \multirow[b]{2}{*}{ Status $^{z}$} & \multicolumn{4}{|c|}{ Adult plant rating $x$} & \multicolumn{2}{|c|}{$\operatorname{Mean}( \pm \text { SD })^{\mathbf{y}}$} \\
\hline & & & BR-2016 & BR-2017 & SP-2016 & SP-2017 & Severity & CI \\
\hline Otana & $\ldots$ & Cultivar & $40 \mathrm{~S}$ & $50 \mathrm{~S}$ & $60 \mathrm{~S}$ & $60 \mathrm{~S}$ & $52.5 \pm 6.6 \mathrm{a}$ & $52.5 \pm 6.6 \mathrm{a}$ \\
\hline PI 197790 & Australia & Uncertain & 30MR & $40 \mathrm{MS}$ & $25 \mathrm{MR}$ & $20 \mathrm{MS}$ & $28.8 \pm 5.5 \mathrm{ab}$ & $17.5 \pm 6.9 \mathrm{~b}$ \\
\hline PI 287298 & Italy & Landrace & 30MR & $30 \mathrm{MS}$ & 30MR & $30 \mathrm{MS}$ & $30 \pm 0 \mathrm{ab}$ & $18 \pm 6.9 \mathrm{~b}$ \\
\hline CIav 4318 & United States & Cultivar & 30MR & $20 \mathrm{MR}$ & 30MS & 40MR & $30 \pm 5.2 \mathrm{ab}$ & $15 \pm 6.8 \mathrm{~b}$ \\
\hline TAM-O-301 & $\ldots$ & Cultivar & $10 \mathrm{MR}$ & $15 \mathrm{MR}$ & $25 \mathrm{MR}$ & $15 \mathrm{MR}$ & $16.3 \pm 3.3 \mathrm{~b}$ & $6.5 \pm 2.5 \mathrm{~b}$ \\
\hline PI 137599 & Argentina & Landrace & $5 \mathrm{R}$ & $1 \mathrm{R}$ & $30 \mathrm{R}$ & $10 \mathrm{R}$ & $11.5 \pm 9.8 \mathrm{~b}$ & $2.3 \pm 0.8 \mathrm{~b}$ \\
\hline PI 140902 & Australia & Cultivar & $5 \mathrm{R}$ & $20 \mathrm{MS}$ & 30MR & $20 \mathrm{R}$ & $18.8 \pm 7.3 \mathrm{~b}$ & $8.3 \pm 3.9 \mathrm{~b}$ \\
\hline PI 140903 & Australia & Uncertain & $10 \mathrm{MR}$ & $20 \mathrm{MR}$ & 20MR & $20 \mathrm{R}$ & $17.5 \pm 2 b$ & $6 \pm 2.3 b$ \\
\hline PI 163404 & Argentina & Unknown & $10 \mathrm{MR}$ & $10 \mathrm{R}$ & 30MR & $10 \mathrm{MS}$ & $15 \pm 7 b$ & $6.5 \pm 3.4 \mathrm{~b}$ \\
\hline PI 168091 & Turkey & Landrace & $20 \mathrm{R}$ & $10 \mathrm{R}$ & $30 \mathrm{MR}$ & $10 \mathrm{R}$ & $17.5 \pm 6.6 b$ & $5 \pm 2.8 \mathrm{~b}$ \\
\hline PI 168092 & Turkey & Landrace & $10 \mathrm{R}$ & $10 \mathrm{R}$ & $25 \mathrm{MR}$ & $10 \mathrm{R}$ & $13.8 \pm 4.5 \mathrm{~b}$ & $4 \pm 3 b$ \\
\hline PI 175023 & India & Landrace & $10 \mathrm{MR}$ & $10 \mathrm{MR}$ & $25 \mathrm{MR}$ & $20 \mathrm{MS}$ & $16.3 \pm 4.5 \mathrm{~b}$ & $8.5 \pm 4.7 b$ \\
\hline PI 177842 & Turkey & Landrace & $10 \mathrm{R}$ & $10 \mathrm{R}$ & $30 \mathrm{MS}$ & $20 \mathrm{MR}$ & $17.5 \pm 6.6 b$ & $9 \pm 7.3 \mathrm{~b}$ \\
\hline PI 186268 & Argentina & Cultivar & $1 \mathrm{R}$ & $10 \mathrm{R}$ & 20MR & $1 \mathrm{R}$ & $8 \pm 6.1 \mathrm{~b}$ & $2.6 \pm 1.7 \mathrm{~b}$ \\
\hline PI 186270 & Argentina & Uncertain & $10 \mathrm{MR}$ & $20 \mathrm{R}$ & 30MR & $5 \mathrm{MS}$ & $16.3 \pm 8.1 \mathrm{~b}$ & $6 \pm 3 b$ \\
\hline PI 186619 & Brazil & Cultivar & $10 \mathrm{MR}$ & $10 \mathrm{R}$ & 30MR & 20MR & $17.5 \pm 6.6 b$ & $6.5 \pm 3.4 \mathrm{~b}$ \\
\hline PI 189628 & Brazil & Uncertain & $10 \mathrm{MR}$ & $10 \mathrm{R}$ & $25 \mathrm{MR}$ & $5 \mathrm{MR}$ & $12.5 \pm 5.7 \mathrm{~b}$ & $4.5 \pm 2.8 \mathrm{~b}$ \\
\hline PI 193040 & Argentina & Unknown & $10 \mathrm{R}$ & $10 \mathrm{R}$ & $20 \mathrm{R}$ & Missing & $13.3 \pm 2.8 \mathrm{~b}$ & $2.7 \pm 0.96 b$ \\
\hline PI 194201 & Uruguay & Uncertain & $5 R$ & $10 \mathrm{R}$ & $30 \mathrm{MR}$ & $10 \mathrm{MR}$ & $13.8 \pm 8.1 \mathrm{~b}$ & $4.8 \pm 2.9 \mathrm{~b}$ \\
\hline PI 198224 & Argentina & Cultivar & $5 R$ & $10 \mathrm{R}$ & $30 \mathrm{MR}$ & $1 \mathrm{MR}$ & $11.5 \pm 8.9 \mathrm{~b}$ & $3.9 \pm 2.4 \mathrm{~b}$ \\
\hline PI 219765 & Greece & Uncertain & $20 \mathrm{MR}$ & $30 \mathrm{MS}$ & $30 \mathrm{MR}$ & $30 \mathrm{MS}$ & $27.5 \pm 2 b$ & $17 \pm 6.2 b$ \\
\hline PI 237090 & Brazil & Uncertain & $10 \mathrm{MR}$ & $10 \mathrm{MR}$ & $25 \mathrm{MR}$ & Missing & $15 \pm 4.1 \mathrm{~b}$ & $6 \pm 2.8 \mathrm{~b}$ \\
\hline PI 244465 & Unknown & Unknown & $5 \mathrm{R}$ & missing & $20 \mathrm{MR}$ & Missing & $12.5 \pm 3.4 \mathrm{~b}$ & $4.5 \pm 2.3 b$ \\
\hline PI 247930 & Brazil & Uncertain & $1 \mathrm{R}$ & $5 \mathrm{R}$ & $30 \mathrm{MR}$ & $10 \mathrm{MR}$ & $11.5 \pm 8.9 \mathrm{~b}$ & $4.3 \pm 2.3 b$ \\
\hline PI 247932 & Brazil & Cultivar & $5 \mathrm{R}$ & $5 \mathrm{R}$ & 30MR & $10 \mathrm{MR}$ & $12.5 \pm 7.9 \mathrm{~b}$ & $4.5 \pm 2.3 b$ \\
\hline PI 285583 & Poland & Cultivar & $20 \mathrm{MR}$ & $30 \mathrm{MS}$ & $20 \mathrm{MR}$ & $10 \mathrm{MR}$ & $20 \pm 5.2 \mathrm{~b}$ & $11 \pm 6.8 \mathrm{~b}$ \\
\hline PI 287288 & Greece & Unknown & $10 \mathrm{R}$ & $10 \mathrm{MR}$ & 20MR & Missing & $13.3 \pm 2.8 \mathrm{~b}$ & $5.3 \pm 2.6 b$ \\
\hline PI 287295 & Italy & Landrace & $20 \mathrm{R}$ & $20 \mathrm{MS}$ & $30 \mathrm{MR}$ & Missing & $23.3 \pm 2 b$ & $15 \pm 5.1 \mathrm{~b}$ \\
\hline PI 287296 & Italy & Landrace & $20 \mathrm{MR}$ & $20 \mathrm{MS}$ & $30 \mathrm{MR}$ & $20 \mathrm{MS}$ & $22.5 \pm 5 b$ & $13 \pm 3.8 b$ \\
\hline PI 287300 & Greece & Landrace & $20 \mathrm{R}$ & $20 \mathrm{MR}$ & $25 \mathrm{MR}$ & $20 \mathrm{MR}$ & $21.3 \pm 1.5 \mathrm{~b}$ & $7.5 \pm 2.5 b$ \\
\hline PI 287302 & Greece & Landrace & $10 \mathrm{R}$ & $10 \mathrm{MR}$ & $35 \mathrm{MR}$ & 20MR & $18.8 \pm 8.8 \mathrm{~b}$ & $7 \pm 3.3 \mathrm{~b}$ \\
\hline PI 287306 & Albania & Landrace & $30 \mathrm{MR}$ & $30 \mathrm{MR}$ & $30 \mathrm{MR}$ & $20 \mathrm{MS}$ & $27.5 \pm 2 \mathrm{~b}$ & $13 \pm 2 b$ \\
\hline PI 287307 & Italy & Landrace & 30MR & $30 \mathrm{MR}$ & $30 \mathrm{MR}$ & $20 \mathrm{MS}$ & $27.5 \pm 2 b$ & $13 \pm 2 b$ \\
\hline CIav 2272 & United States & Uncertain & $30 \mathrm{MR}$ & $10 \mathrm{R}$ & $25 \mathrm{MR}$ & $10 \mathrm{R}$ & $18.8 \pm 7.3 \mathrm{~b}$ & $6.5 \pm 3.3 \mathrm{~b}$ \\
\hline CIav 3390 & United States & Cultivar & $20 \mathrm{MR}$ & $30 \mathrm{MS}$ & $30 \mathrm{MR}$ & $20 \mathrm{MR}$ & $25 \pm 6.6 \mathrm{~b}$ & $15 \pm 9.5 \mathrm{~b}$ \\
\hline CIav 3412 & United States & Cultivar & 30MR & $20 \mathrm{MS}$ & $35 \mathrm{MR}$ & $20 \mathrm{MS}$ & $26.3 \pm 4.5 \mathrm{~b}$ & $14.5 \pm 1.9 \mathrm{~b}$ \\
\hline CIav 4042 & United States & Cultivar & $10 \mathrm{R}$ & $20 \mathrm{MS}$ & $40 \mathrm{MS}$ & $30 \mathrm{MS}$ & $25 \pm 9.9 \mathrm{~b}$ & $18.5 \pm 9.7 \mathrm{~b}$ \\
\hline CIav 4097 & United States & Cultivar & $40 \mathrm{MR}$ & $20 \mathrm{MS}$ & $30 \mathrm{MS}$ & $20 \mathrm{MS}$ & $27.5 \pm 6.6 \mathrm{~b}$ & $18 \pm 4 b$ \\
\hline
\end{tabular}

${ }^{x}$ Abbreviations: $\mathrm{S}=$ susceptible, $\mathrm{MS}=$ moderately susceptible, $\mathrm{MR}=$ moderately resistant, and $\mathrm{R}=$ resistant.

${ }^{\mathrm{y}} \mathrm{SD}=$ standard deviation and $\mathrm{CI}=$ coefficient of infection. Means followed by the same letter in a column are not significantly different $(\alpha=0.05)$.

${ }^{\mathrm{z}}$ Improvement status. 
uredinia without chlorosis or necrosis (S) (McCartney et al. 2011). Ninety-seven accessions that were not susceptible (with infection response R, MR, and MS) in Baton Rouge were further evaluated at the Matt Moore Buckthorn Nursery of the Cereal Disease Laboratory (CDL) in St. Paul, MN in summer 2016. The test at the CDL was conducted following experimental procedures similar to those in Baton Rouge, except that two resistant (TAM-O-301 and MN841801) and two susceptible (Otana and Protégé) oat genotypes were planted every 20 rows. The average coefficient of infection (CI) was calculated from the two field scores (severity on modified Cobb scale and the infection response). The scores were converted to CI by multiplying severity by an assigned constant value for the field response $(\mathrm{R}=0.2, \mathrm{MR}=0.4, \mathrm{MS}=0.8$, and $\mathrm{S}=1.0)($ Stubbs et al. 1986). Thirty-six accessions that were not susceptible in either location and with $\mathrm{CI} \leq 20$ were further evaluated in Baton Rouge and St. Paul in 2017. The same accessions were also used in the seedling resistance tests.

Evaluation of landraces for seedling resistance. The 36 accessions that were not susceptible at either field location were tested for seedling resistance against eight $P$. coronata $\mathrm{f}$. sp. avenae races. In addition, $P c$ differential lines were included in the seedling evaluation. A single pustule from each of the eight races was propagated on Otana plants. Three or four seeds of each test material were sown in 3.8-cm-diameter cone-tainers containing a 3:2:2 ( $\mathrm{vol} / \mathrm{vol} / \mathrm{vol}) \mathrm{mix}$ of sand, peat moss, and vermiculite in a greenhouse. The experiment was conducted in two replications. Two weeks after planting, seedlings were inoculated with uredinia of each race suspended in Soltrol170 isoparaffin (Chevron Phillips, The Woodlands, TX) using a motorized sprayer (GAST Manufacturing, Inc., Benton Harbor, MI) and a small atomizer (G-R Manufacturing Manhattan, KS). Plants were left in the open for $1 \mathrm{~h}$ to dry, then transferred to a dew chamber set at $20^{\circ} \mathrm{C}$ with no light. After $18 \mathrm{~h}$ in the dew chamber, plants were placed in a growth chamber adjusted to 20 to $22^{\circ} \mathrm{C}$ with an 18 -h photoperiod. Genotype reactions to each $P$. coronata $\mathrm{f}$. sp. avenae race were recorded as infection type (IT) on the first and second leaves 14 days after inoculation. IT were based on a 0-to-4 scale (Chong et al. 2000), with + and - indicating intermediate types. Infection types 0 to $2+$ were considered resistant and 3- to 4+ susceptible. The tests were repeated and, when there was discrepancy in disease rating between the first and second test, a third test was conducted.

Growth chamber evaluation of accessions for APR. Three accessions (CIav 2272, CIav 3390, and PI 285583) that were susceptible to the eight $P$. coronata $\mathrm{f}$. sp. avenae races at the seedling stage but resistant in the field were evaluated in the growth chamber to confirm their APR status. Seed of the three accessions and checks (Otana and TAM-O-301) were planted in containers and placed in a

Table 3. Mean disease severity, coefficient of infection, and standard error (SE) on Otana and TAM-O-301 in Baton Rouge (BR-16 and BR-17) and St. Paul (SP-16 and SP-2017)

\begin{tabular}{|c|c|c|c|c|c|c|c|c|}
\hline \multirow[b]{2}{*}{ Cultivar } & \multicolumn{4}{|c|}{ Disease severity $( \pm \mathrm{SE})$} & \multicolumn{4}{|c|}{ Coefficient of infection $( \pm \mathrm{SE})$} \\
\hline & BR-16 & BR-17 & SP-16 & SP-17 & BR-16 & BR-17 & SP-16 & SP-17 \\
\hline Otana & $40 \pm 2.2$ & $50 \pm 1.7$ & $60 \pm 2.1$ & $60 \pm 1.9$ & $40 \pm 2.2$ & $50 \pm 1.7$ & $60 \pm 2.1$ & $60 \pm 1.9$ \\
\hline TAM-O-301 & $10 \pm 1.1$ & $15 \pm 1.1$ & $25 \pm 0.9$ & $15 \pm 1.0$ & $3.7 \pm 0.38$ & $4.9 \pm 0.58$ & $10 \pm 0.34$ & $5.3 \pm 0.31$ \\
\hline
\end{tabular}

Table 4. Infection types produced by eight Puccinia coronata f. sp. avenae races on $31 P c$ gene differentials ${ }^{z}$

\begin{tabular}{|c|c|c|c|c|c|c|c|c|c|}
\hline \multirow[b]{2}{*}{ Differential } & \multirow[b]{2}{*}{$P c$ gene } & \multicolumn{8}{|c|}{ Race designation } \\
\hline & & MGBH & LLMG & LCBB & LQBG & MGLB & NSGG & LSGG & LBBB \\
\hline Ascencao & Pcl4 & 3 & $3+$ & 3 & 4 & 34 & 3 & 4 & 3 \\
\hline D-137 & Pc35 & 0 & 0 & ; & 3 & 4 & ; & 2 & 1 \\
\hline CI 8081 & Pc36 & $33-$ & 3 & ; & 3 & 34 & 34 & 4 & ; \\
\hline CW491-4 & Pc38 & $21+$ & 34 & ; & 3 & $; 1$ & 3 & 4 & $; 1$ \\
\hline F-366 & Pc39 & 4- & $; 0$ & ; & 4 & 3 & 4 & 34 & 1 \\
\hline F-83 & Pc40 & 4 & 3 & 3 & 43 & 3 & $34-$ & 43 & 4 \\
\hline F-169 & Pc45 & 0 & 0 & ; & ; & ;1- & ; & ; & 0 \\
\hline F-290 & Pc46 & $1+2$ & $; 1-$ & ;1- & ; & ; & $3-$ & 2 & $; 1-$ \\
\hline F-158 & Pc48 & 0 & 0 & 0 & ; & $; 1$ & 4 & $34-$ & 0 \\
\hline CW-486 & Pc50 & 3 & 0 & ; & ; & 0 & 0 & 0 & ; \\
\hline Wahl number 8 & Pc51 & $; 0$ & 3 & ; & ; & 2 & ; & ; & 2 \\
\hline Wahl number 2 & Pc52 & 0 & $; 0$ & ; & ; & ; & $33-$ & $3+$ & 0 \\
\hline $6-112-1-15$ & Pc53 & 34 & $; 0$ & 0 & ; & 0 & ; & $; 0$ & 0 \\
\hline CAV 1832 & Pc54 & 0 & 0 & $11+$ & ; & ;1- & ; & ; & ; \\
\hline CAV 4963 & Pc55 & 4 & ; & ; & 43 & 3 & 34 & $34-$ & ; \\
\hline CAV 1964 & Pc56 & 4 & $43+$ & $; 1-$ & 3 & $; 1$ & 34 & $34-$ & 2 \\
\hline CI 8295 & Pc57 & 3 & $3-$ & ; & $; 1$ & $; 1$ & 3 & 34 & $1+2$ \\
\hline TAM-O-301 & Pc58 & 0 & 0 & 0 & ; & $; 1$ & ; & ; & 0 \\
\hline TAM-O-312 & Pc59 & 1 & $34-$ & ; & $; 1$ & ; & ; & ; & 1 \\
\hline Coker 227 & Pc60 & 3 & ;2 & $1+$ & $; 1$ & ; & 2 & $1-$ & 0 \\
\hline Coker 234 & Pc61 & 3 & 3 & 3 & 2 & $11+$ & $; 1$ & 2 & 2 \\
\hline Fraser Pc62 & Pc62 & ;1- & ; & $; 0$ & ; & ; & ; & ; & $; 0$ \\
\hline Fraser Pc63 & Pc63 & 3 & 0 & ;0 & 0 & ; & $11+$ & $22+$ & 0 \\
\hline Makuru//Sun II Pc64 & Pc64 & 4- & 0 & ; & 2 & ; & ; & ; & ; \\
\hline Makuru//Sun II Pc67 & Pc67 & 4- & 4 & $1+$ & $; 1$ & $1+$ & 2 & 2 & 1 \\
\hline Makuru//Sun II Pc68 & Pc68 & 0 & $01+$ & $3+$ & 0 & 0 & ; & ; & 0 \\
\hline H547 & Pc70 & ; & ; & ; & 43 & 3 & ; & ; & $; 1$ \\
\hline IA Y345 & $P c 71$ & $2+$ & ; & $; 0$ & $; 1$ & 4 & 3 & 3 & ; \\
\hline \multirow[t]{3}{*}{ Amagalon } & Pc91 & 0 & ; & $; 0$ & 0 & ; & ; & ; & 0 \\
\hline & Pc94 & 0 & ; & $; 1-$ & ; & ; & ; & ; & ; \\
\hline & Pc96 & 0 & 3 & 34 & 3 & $3-$ & 3 & 3 & 0 \\
\hline
\end{tabular}

${ }^{\mathrm{z}}$ Based on the 0-to-4 scale described by Chong et al. (2000). 
greenhouse. Later, the flag leaf of each plant was inoculated with uredinia of the eight $P$. coronata $\mathrm{f}$. sp. avenae races used in the seedling evaluation and placed in a growth chamber adjusted to 20 to $22^{\circ} \mathrm{C}$ with an 18-h photoperiod. Flag leaves were evaluated for infection response and disease severity 2 weeks after inoculation. The experiment was repeated following the same procedure as above. Both experiments were conducted in three replications.

Statistical analyses. Standard error of disease severity and CI within field plots in each location-year was estimated using the replicated data of Otana and TAM-O-301. Data for disease severity and CI from Baton Rouge and St. Paul in the 2 years were subjected to analysis of variance. When there was significance difference for disease severity or CI among accessions, post hoc multiple comparison of means was performed using the Tukey's studentized range test (honestly significant difference). All statistical tests were performed using the software SAS Enterprise Guide v. 7.1 (SAS Institute 2014).

\section{Results}

Field resistance. Of the 607 oat accessions tested in Baton Rouge in 2016, most (84\%) had an infection response of S. The remaining 97 accessions (16\%) were MS, MR, or R (Table 1). These 97 accessions were selected for further evaluation at the buckthorn nursery in St. Paul. The raw data for the 607 oat accessions was submitted to the GRIN (https://www.ars-grin.gov/npgs/).
In St. Paul, 72 of 97 accessions (74.2\%) exhibited MR infection response, followed by MS $(22.7 \%)$ and $\mathrm{R}(2.1 \%)$. One accession, PI 174543, which exhibited an MR infection response in Baton Rouge, was S in St. Paul. Most accessions rated as R in Baton Rouge exhibited MR or MS reactions in St. Paul.

Of the 97 accessions tested at both field locations in 2016, one was discarded for having an S reaction in St. Paul, and 60 accessions were dropped because their mean CI was above 20. The remaining 36 accessions with infection responses of MS, MR, or R in both locations and a mean $\mathrm{CI} \leq 20$ were selected for a second round of field evaluations and for seedling tests.

After testing the 36 accessions in two locations for 2 years (four location-years), the mean CI was 7.2 (range: 0.6 to 20) at Baton Rouge and 11.9 (range: 4 to 20) at St. Paul. The average disease severity of the 36 accessions was 16\% (range: 3 to 35\%) at Baton Rouge and $22.2 \%$ (range: 10.5 to $35 \%$ ) at St. Paul. The mean CI and disease severity of the resistant check, TAM-O-301, were 6.5 and $16.3 \%$, respectively, while the susceptible check, Otana, had a $\mathrm{CI}$ and average disease severity of 52.5 and $52.5 \%$, respectively (Table 2). Standard errors of mean disease severity and CI in BR2016, BR-2017, SP-2016, and SP-207 on Otana and TAM-O-301 are presented in Table 3.

Analysis of variance showed highly significant differences $(P<$ 0.0001 ) for disease severity and CI (Table 2). In all, 33 of 36

Table 5. Reaction of 36 oat accessions to eight Puccinia coronata $f$. sp. avenae races at seedling stage

\begin{tabular}{|c|c|c|c|c|c|c|c|c|c|c|}
\hline \multirow[b]{2}{*}{ Accession } & \multirow[b]{2}{*}{ Origin } & \multirow[b]{2}{*}{ Status $^{\mathbf{z}}$} & \multicolumn{8}{|c|}{ Seedling resistance $^{\mathrm{y}}$} \\
\hline & & & MGBH & LLMG & LCBB & LQBG & MGLB & NSGG & LSGG & LBBB \\
\hline Otana & $\ldots$ & Cultivar & 3 & $43+$ & $3+$ & 3 & 3 & 3 & 3 & 3 \\
\hline TAM-O-301 & $\ldots$ & Cultivar & $; 0$ & ; & ; & $; 1$ & 0 & ; & 0 & $; 0$ \\
\hline PI 137599 & Argentina & Landrace & $1+$ & ; & $; 1+$ & 3 & 1 & $2 \mathrm{~N}$ & $3+$ & 0 \\
\hline PI 140902 & Australia & Cultivar & $1+$ & $2 \mathrm{C}$ & $3 \mathrm{C}$ & 4 & 3 & $2+\mathrm{N}$ & 3 & $2 \mathrm{C}$ \\
\hline PI 140903 & Australia & Uncertain & 3 & $2 \mathrm{C}$ & 3 & $43 \mathrm{C}$ & 3 & 4 & $3+$ & 3 \\
\hline PI 163404 & Argentina & Unknown & 3 & $2+$ & 3 & $43 \mathrm{C}$ & 1 & $2 \mathrm{~N}$ & 3 & 2 \\
\hline PI 168091 & Turkey & Landrace & ; & $; 1$ & $2 \mathrm{C}$ & $1+$ & 2 & 4 & 4 & ; \\
\hline PI 168092 & Turkey & Landrace & 0 & $; 1-$ & $1+$ & $2 \mathrm{C}$ & $3+$ & $3 \mathrm{~N}$ & $3 N$ & $; 1+$ \\
\hline PI 175023 & India & Landrace & $1+$ & $3 \mathrm{~N}$ & 4 & $3 \mathrm{~N}$ & $; 1$ & 4 & 2 & $; 1+$ \\
\hline PI 177842 & Turkey & Landrace & ;12- & $; 1$ & $1 ;$ & $11+$ & 3 & 4 & 34 & ; \\
\hline PI 186268 & Argentina & Cultivar & $1+$ & $3 \mathrm{~N}$ & $3 \mathrm{~N}$ & 3 & $1+2 \mathrm{~N}$ & 4 & 2 & ;1- \\
\hline PI 186270 & Argentina & Uncertain & 3 & $3-$ & 3 & $3 \mathrm{C}$ & ;1 & 1 & $; 1$ & 1 \\
\hline PI 186619 & Brazil & Cultivar & 2 & $2-$ & $3 \mathrm{~N}$ & $3 C$ & ; & 1 & ; & 1 \\
\hline PI 189628 & Brazil & Uncertain & 1 & 2 & $3 \mathrm{~N}$ & 43 & $11+$ & 1 & 2 & 1 \\
\hline PI 193040 & Argentina & Unknown & 0 & ; & $1+^{\mathrm{a}}$ & $; 1+$ & ;1- & $2 \mathrm{~N}$ & 2 & 0 \\
\hline PI 194201 & Uruguay & Uncertain & 0 & 1 & $; 1$ & $; 1-$ & $; 0$ & 0 & $; 0$ & $; 1$ \\
\hline PI 197790 & Australia & Uncertain & $1+$ & 2 & 23 & $3 \mathrm{~N}$ & 3 & 3 & $22+$ & 1 \\
\hline PI 198224 & Argentina & Cultivar & $; 1$ & 2 & 3 & $3 \mathrm{~N}$ & $21+$ & 4 & 2 & 1lif \\
\hline PI 219765 & Greece & Uncertain & 3 & 2 & 3 & 3 & 3 & 4 & 34 & 2 \\
\hline PI 237090 & Brazil & Uncertain & 2 & 2 & 2 & $22+$ & 2 & 2 & 2 & 2 \\
\hline PI 244465 & Unknown & Unknown & $; 1+$ & ;C & $3+$ & $; 1$ & ; & $2 \mathrm{~N}$ & 21 & $11+$ \\
\hline PI 247930 & Brazil & Uncertain & 0 & 0 & ; & 2 & ; l lif & 0 & $; 1$ & ; \\
\hline PI 247932 & Brazil & Cultivar & $3-$ & $3-\mathrm{N}$ & $3-$ & $3 N$ & ; & $; 1$ & ;0 & 1 lif \\
\hline PI 285583 & Poland & Cultivar & $34-$ & 3 & 3 & 3 & 3 & 3- & 3 & 3 \\
\hline PI 287288 & Greece & Unknown & $22+$ & $2-$ & $2 \mathrm{~N}$ & $2+\mathrm{N}$ & $3 \mathrm{~N}$ & 4 & 3 & ; \\
\hline PI 287295 & Italy & Landrace & 0 & 2 & 3 & $21+$ & $34-$ & $34-$ & $22+$ & 0 \\
\hline PI 287296 & Italy & Landrace & $3-$ & 2 & 4 & 43 & 3 & 34 & 34 & 3 \\
\hline PI 287298 & Italy & Landrace & 3 & 2 & 4 & 4 & 3 & $43+$ & 4 & 23 \\
\hline PI 287300 & Greece & Landrace & 0 & 2 & $3+4$ & $3+$ & 2 & 3 & $2 \mathrm{C}$ & 2 lif \\
\hline PI 287302 & Greece & Landrace & 0 & ; & 4 & $3 \mathrm{~N}^{\mathrm{b}}$ & $32+$ & 4 & $3+$ & $11+$ \\
\hline PI 287306 & Albania & Landrace & ; & 2 & $3 \mathrm{~N}$ & $32+$ & 3 & $3+$ & $2 \mathrm{~N}$ & 2 \\
\hline PI 287307 & Italy & Landrace & $1+$ & 2 & 3 & 3 & 3 & 3 & 3 & $2+$ \\
\hline CIav 2272 & United States & Uncertain & 3 & 3 & 4 & 3 & 3 & 3 & 3 & 3 \\
\hline CIav 3390 & United States & Cultivar & 3 & 3 & $3+$ & 4 & 3 & 3 & 3 & 3 \\
\hline CIav 3412 & United States & Cultivar & 34 & 3 & 3 & 4 & 2 & $3+$ & 3 & 3 \\
\hline CIav 4042 & United States & Cultivar & 3 & 2 & 3 & 3 & $2 \mathrm{~N}$ & $11+$ & 3 & 2 \\
\hline CIav 4097 & United States & Cultivar & 34 & 3 & 4 & $3 \mathrm{C}$ & 2 & $1+$ & 2 & 2 \\
\hline CIav 4318 & United States & Cultivar & 3 & 3 & 4 & $3 \mathrm{C}$ & 2 & $2 \mathrm{~N}$ & 34 & 4 \\
\hline
\end{tabular}

${ }^{y}$ Symbols: + or - after infection type (0-to-4 scale) denotes the level of intensity of infection, $\mathrm{C}=$ chlorosis, $\mathrm{N}=$ necrosis, and lif $=$ low infection frequency. ${ }^{\mathrm{z}}$ Improvement status. 
accessions had significantly lower disease severity than Otana. Only three accessions (namely, CIav 4318, PI 197790, and PI 287298) were not significantly different from Otana based on disease severity. On the other hand, all 36 oat accessions and TAM-O-301 had significantly lower CI than Otana. However, there was no significant difference in severity and CI between the 36 accessions and TAMO-301 (Table 2).

South America had the highest proportion of accessions with infection responses of MS, MR, and R with 77.3\%; followed by Australia, North America, Asia, Africa, and Europe with 47.1, 22.1, 13, 10.5 , and $7.4 \%$, respectively (Table 1 ).

Seedling resistance. Thirty-six accessions that were not susceptible in the first round of tests at Baton Rouge and St. Paul, with mean $\mathrm{CI} \leq 20$, and $31 P c$ differential lines were evaluated using eight $P$. coronata f. sp. avenae races. The seedling IT of the $P c$ differential lines to the eight $P$. coronata $\mathrm{f}$. sp. avenae races is described in Table 4. Three accessions (CIav 2272, CIav 3390, and PI 285583) produced compatible IT to all races, indicating a lack of seedling resistance to the races used in this study. The remaining 33 accessions exhibited resistance to at least one race. We categorized these into two groups: (i) accessions with IT patterns similar to one or more of the $P c$ differential lines and (ii) accessions with IT patterns not similar to any of the $P c$ differential lines.

One accession, PI 177842, originating from the Mediterranean region of Turkey, had an IT pattern similar to the $P c 71$ differential line, suggesting the possible presence of this seedling resistance gene (Tables 4 and 5). Three accessions (PI 193040, PI 194201, and PI 247930) produced incompatible IT to all the $P$. coronata f. sp. avenae races used in the study. In terms of susceptibility and resistance, these three accessions had similar disease reaction with four $P c$ differential lines (Pc54, Pc58, Pc91, and Pc94).

There were 28 accessions that exhibited compatible reactions with one or more races but their IT patterns did not match any of the differential lines (Table 5).

APR in the growth chamber. The three accessions that had crown rust resistance in the field tests but that were susceptible to all races at the seedling stage had MR to MS disease reactions when inoculated in growth chambers at the adult plant stage (Table 6). Accession CIav 3390 was MR against all of the $P$. coronata f. sp. avenae races used in the study, while accessions CIav 2272 and PI 285583 were MS to six races and MR to two races (Table 6). Otana, the susceptible check, had disease reactions of S to MS, while TAMO-301, the resistant check, was R or MR to all the races as adult plants in the growth chambers in two independent tests (Table 6).

\section{Discussion}

Field resistance tests were conducted in two locations for two seasons. APR is selected in the field and, to reliably identify resistance lines, disease assays must optimize either natural infections or induce epidemics (Ellis et al. 2014). The St. Paul location is ideal to test oat genotypes for crown rust resistance because the nursery is surrounded by the alternate host of $P$. coronata $\mathrm{f}$. sp. avenae in order to create maximum disease pressure and race diversity. As expected, there was high disease pressure in both locations, as shown by high disease severity on the susceptible check cultivar throughout both fields (range: $40 \mathrm{~S}$ to $60 \mathrm{~S}$ ). Statistical tests also showed low standard error for disease severity and CI on Otana and TAM-O-301 in all location-years (Table 3). These disease-conducive environments enabled reliable resistance testing in both years.

Of the 607 accessions tested against naturally occurring inoculum in the field, 97 were identified with some level of field resistance, having infection responses ranging from MS to R. Although 1 accession selected as R in Baton Rouge was S in St. Paul, 11 of 20 randomly selected $\mathrm{S}$ accessions in Baton Rouge were $\mathrm{R}$ in St. Paul (data not shown). In addition, of the 25 accessions that showed a disease reaction of R in Baton Rouge, only 2 (PI 137599 and PI 193040) had a similar disease reaction in St. Paul. Such variability was expected because the virulence of $P$. coronata $\mathrm{f}$. sp. avenae varies from location to location (Carson 2011).

The seedling tests on 36 field-resistant accessions identified CIav 2272, CIav 3390, and PI 285583 as being susceptible to all races, suggesting that the resistance in these accessions was not due to major genes that are effective at the seedling stage. This result, coupled with their field reactions of MR with reduced pustule size, suggested APR. Their four location-year mean CI values were also in the low range and similar to the resistant check, TAM-O-301 (Fig. 1). The field observation was further supported by growth chamber tests at the flag leaf stage, where CIav 3390 showed moderate APR. The other two accessions (CIav 2272 and PI 285583) were MR to MS in adult plant growth chamber tests. According to Portyanko et al. (2005), APR in oat to crown rust is expressed as a type of quantitative resistance with reduced pustule size, reduced spore production, and

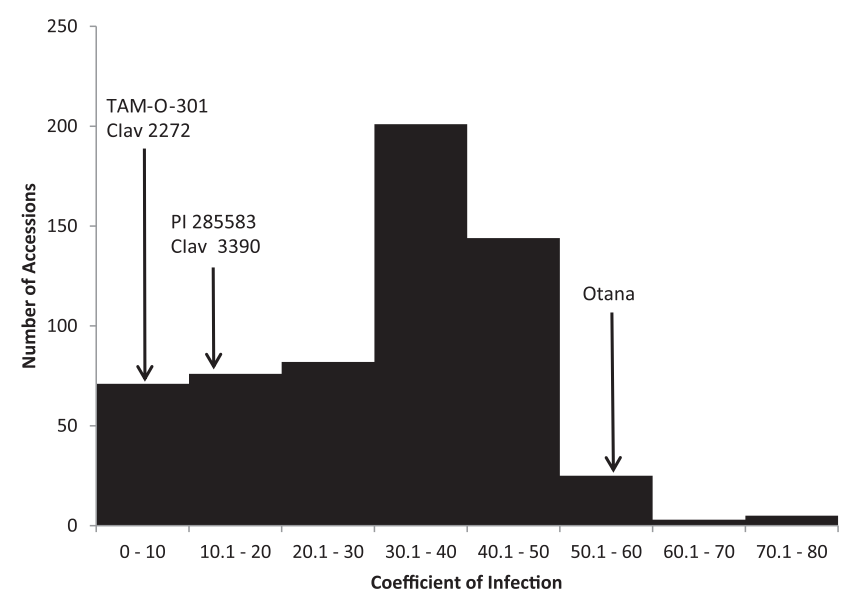

Fig. 1. Distribution of coefficient of infection values for 607 oat accessions based on an adult plant evaluation conducted at Baton Rouge, LA in 2016. The coefficient of infection values shown by the arrows for TAM-0-301, Clav 2272, Clav 3390, PI 285583 , and Otana are the means of four location-years.

Table 6. Mean disease severity and infection response of suspected adult plant resistance accessions, CIav 3390, CIav 2272, and PI 285583; susceptible check cultivar Otana; and resistant check cultivar TAM-O-301 against eight Puccinia coronata f. sp. avenae races after inoculation at the adult plant stage and incubation in a growth chamber for 14 days $^{\mathrm{z}}$

\begin{tabular}{|c|c|c|c|c|c|c|c|c|c|c|}
\hline \multirow[b]{2}{*}{ Race } & \multicolumn{5}{|c|}{ Experiment 1} & \multicolumn{5}{|c|}{ Experiment 2} \\
\hline & CIav 3390 & CIav 2272 & PI 285583 & TAM-O-301 & $\overline{\text { Otana }}$ & CIav 3390 & CIav 2272 & PI 285583 & TAM-O-301 & Otana \\
\hline MGBH & $5 \mathrm{MR}$ & $5 \mathrm{MR}$ & TrMR & TrRMR & $5 \mathrm{MS}$ & $10 \mathrm{MR}$ & $10 \mathrm{MR}$ & $10 \mathrm{MR}$ & $5 \mathrm{MR}$ & $25 \mathrm{MS}$ \\
\hline LLMG & $20 \mathrm{MR}$ & $50 \mathrm{MS}$ & $10 \mathrm{MS}$ & 5RMR & $35 \mathrm{MSS}$ & $20 \mathrm{MR}$ & 40MS & $10 \mathrm{MS}$ & TrMR & $30 \mathrm{MSS}$ \\
\hline LCBB & $20 \mathrm{MR}$ & $35 \mathrm{MS}$ & $20 \mathrm{MS}$ & 10RMR & 40MSS & $15 \mathrm{MR}$ & 30MS & $15 \mathrm{MS}$ & 5RMR & $45 \mathrm{MSS}$ \\
\hline LQBG & $30 \mathrm{MR}$ & 40MS & $30 \mathrm{MS}$ & 5RMR & $20 \mathrm{MS}$ & $25 \mathrm{MR}$ & 40MS & $30 \mathrm{MS}$ & 5RMR & $25 \mathrm{MS}$ \\
\hline MGLB & $15 \mathrm{MR}$ & $10 \mathrm{MS}$ & $10 \mathrm{MS}$ & $15 \mathrm{MR}$ & $35 \mathrm{MS}$ & $20 \mathrm{MR}$ & $20 \mathrm{MS}$ & $15 \mathrm{MS}$ & $10 \mathrm{MR}$ & $40 \mathrm{MS}$ \\
\hline NSGG & $30 \mathrm{MR}$ & 40MS & $20 \mathrm{MS}$ & $10 \mathrm{MR}$ & 40MSS & $25 \mathrm{MR}$ & $30 \mathrm{MS}$ & $20 \mathrm{MS}$ & $10 \mathrm{MR}$ & $35 \mathrm{MSS}$ \\
\hline LSGG & $30 \mathrm{MR}$ & $30 \mathrm{MS}$ & $20 \mathrm{MS}$ & 10RMR & 30MSS & $20 \mathrm{MR}$ & $30 \mathrm{MS}$ & $20 \mathrm{MS}$ & 10RMR & $35 \mathrm{MSS}$ \\
\hline LBBB & $20 \mathrm{MR}$ & $10 \mathrm{MR}$ & $10 \mathrm{MR}$ & 10RMR & $20 \mathrm{MS}$ & $20 \mathrm{MR}$ & $10 \mathrm{MR}$ & $10 \mathrm{MR}$ & $5 \mathrm{MR}$ & $30 \mathrm{MS}$ \\
\hline
\end{tabular}

${ }^{\mathrm{z}}$ Abbreviations: $\mathrm{S}$ = susceptible, $\mathrm{MS}$ = moderately susceptible, $\mathrm{MR}=$ moderately resistant, and $\mathrm{R}=$ resistant. 
extended latent period. Quantitative resistance is usually preferred over major gene resistance to achieve durable resistance against various cereal rusts (Ellis et al. 2014; Lin et al. 2014; Portyanko et al. 2005). Quantitative resistance is likely more important in the case of oat, given the fact that major gene resistance often loses its effectiveness in less than 5 years (Carson 2011; Chong and Kolmer 1993; Leonard et al. 2004; McCallum et al. 2007). Hence, the three landraces in general, and CIav 3390 in particular, could be potential sources of APR to crown rust. The genes responsible were not characterized in the present study, other than to show that they were not effective at the seedling stage. For all other accessions, further investigation is required to determine the basis of the field resistance because it could be race specific, as has been shown in wheat against yellow rust and leaf rust (Dyck et al. 1966; Milus et al. 2015), due to either the additive effects of minor genes or to the combined presence of several major genes, each effective against part of the pathogen population, resulting in less disease in the field when exposed to a mixture of races.

Four accessions (PI 193040, PI 194201, PI 237090, and PI 247930 ) were resistant to all eight $P$. coronata $\mathrm{f}$. sp. avenae races used in the present study, indicating broad-spectrum resistance similar to four of the $P c$ gene differentials. The resistance in these accessions may be due to either one or more of these $P c$ genes or to combinations of other $P c$ genes. On the other hand, 28 accessions had unique virulence patterns not similar to any of the $P c$ differential lines but with some similarities to each other. Sometimes the accessions differed by only one single-race reaction. For example, PI 287295 was similar to PI 197790, except for additional effectiveness to race LQBG. CIav 4318 was similar to CIav 3412, except for additional effectiveness to race NSGG. Also, PI 186270 was similar to CIav 4318 and PI 186619 to PI 175023, except for additional effectiveness to two races each. These accessions may carry $P c$ genes that are not currently characterized. However, further investigation is needed to confirm whether novel genes are present and to determine how they can be deployed most effectively by breeders.

The high proportion of resistance in accessions from South America may be associated with coevolution of the accessions with the high virulence complexity and diversity of $P$. coronata $\mathrm{f}$. sp. avenae isolates in the continent (Leonard and Martinelli 2005). PI 194201, originating from Uruguay, is of particular interest because, according to the GRIN database (https://www.ars-grin.gov/npgs/), this accession has resistance to multiple diseases, including stem rust, barley yellow dwarf, and smut, which are all important diseases of oat. This accession could prove valuable for oat breeding programs.

The proportion of resistant accessions in the A. sativa gene pool evaluated (16\%) was low compared with the resistance in the gene pool of wild oat relatives. For example, Tan and Carson (2013) reported resistance at the seedling as well as the adult plant stage in $45 \%$ of 332 accessions of 11 wild oat species originating from Morocco. Though at the seedling stage, Sowa et al. (2016) and Cabral and Park (2014) also reported that 25, 68, 56, 68, and 25\% of accessions of A. magna, A. murphyi A. insularis, A. strigosa, and $A$. barbata, respectively, had resistance against crown rust when tested using $P$. coronata f. sp. avenae isolates from Poland and Australia. Most of the $P c$ genes currently deployed in cultivated oat were derived from the diploid species A. strigosa and the wild hexaploid oat $A$. sterilis (Simons et al. 1978). Other species such as A. barbata, A. vavilova, A. abysinnica, A. magna, and A. longiglumus have also been identified as sources of crown rust resistance (Cabral and Park 2014; Tan and Carson 2013). The transfer of genes from wild relatives to cultivated oat is difficult and sometimes impossible (Sowa et al. 2016; Tan and Carson 2013) due to barriers arising from ploidy level differences (Jellen and Leggett 2006). Of the many Pc genes identified from wild relatives, only a few have been transferred to cultivated hexaploid oat due to interspecies crossing barriers. These include the first successful transfer of a resistance gene from the wild hexaploid A. sterilis to cultivated oat (Simons 1985), the transfer of Pc94 from A. strigosa to cultivars Leggett and Stride (Aung et al. 1996), and the transfer of $P c 91$ from A. magna to cultivar HiFi (McMullen et al. 2005). Obtaining resistance sources from the cultivated hexaploid gene pool for a major disease such as crown rust eliminates problems associated with gene transfer from a different species, as well as overcomes the obstacle associated with suppression or inhibition of gene expression after interspecific gene transfer (Hegarty et al. 2008; Rines et al. 2007). Because of these challenges, Sowa et al. (2016) recommended the use of accessions whose ploidy level was verified as hexaploid as a promising alternative to using tetraploid oat as a source of resistance. The present study showed that the hexaploid gene pool is a rich source of resistance to crown rust, possibly enabling the unhindered transfer of genes to locally adapted germplasm and facilitating the development of new disease resistant cultivars. Although sourcing resistance within the species overcomes the technical barrier, linkage drag will remain a challenge in any hybridization program.

Comparison of accessions for their field response to crown rust with previous evaluations (GRIN, https://www.ars-grin.gov/npgs/) showed that, of the 225 accessions 190 (84.4\%) and $12(5.3 \%)$ had the same susceptible and resistance field responses, respectively. However, 21 accessions that were previously susceptible exhibited some level of resistance in the current study, and two accessions that were resistant in the earlier studies had a susceptible response now. Change in the susceptibility of accessions against $P$. coronata f. sp. avenae is expected because of the continuous emergence of new races on the alternate host (Carson 2011). Accession PI 247930, from Brazil, showed a particularly consistent field response of R and MR across locations and over time: Ames, IA in 1983 (1R), St. Paul, MN in 1994 (20R), Baton Rouge, LA in 2015-16 (1R/5R), and St. Paul, MN in 2016-17 (30MR/10MR)

Accessions that were identified in the present study with APR and seedling resistance will diversify the resistance sources for crown rust resistance breeding. With a high rate of virulence evolution in the $P$. coronata f. sp. avenae population, emphasis should be given to breeding cultivars with APR and pyramiding of seedling resistance $P c$ genes to develop cultivars more likely to exhibit durable resistance against crown rust. The accessions identified in this study will contribute to such work.

\section{Acknowledgments}

We thank R. Caspers of the USDA Cereal Disease Laboratory and A. Lunos of Louisiana State University AgCenter-SPESS for their assistance in the field experiments.

\section{Literature Cited}

Acevedo, M., Jackson, E. W., Chong, J., Rines, H. W., Harrison, S., and Bonman, J. M. 2010. Identification and validation of quantitative trait loci for partial resistance to crown rust in oat. Phytopathology 100:511-521.

Aung, T., Chong, J., and Leggett, M. 1996. The transfer of crown rust resistance gene $P c 94$ from a wild diploid to cultivated hexaploid oat. Pages 167-171 in: Proc. 9th Eur. Mediterr. Cereal Rusts Powdery Mildews Conf. G. H. J. Kema, R. E. Niks, and R. A. Daamen, eds. European and Mediterranean Cereal Rust Foundation, Wageningen and Lunteren, The Netherlands.

Babiker, E. M., Gordon, T. C., Jackson, E. W., Chao, S., Harrison, S. A., Carson, M. L., Obert, D. E., and Bonman, J. M. 2015. Quantitative trait loci from two genotypes of oat (Avena sativa) conditioning resistance to Puccinia coronata. Phytopathology 105:239-245.

Bariana, H. S., Brown, G. N., Bansal, U. K., Miah, H., Standen, G. E., and Lui, M 2007. Breeding triple rust resistant wheat cultivars for Australia using conventional and marker-assisted selection technologies. Aust. J. Agric. Res. 58:576-587.

Basnet, B. R., Singh, R. P., Herrera-Foessel, S. A., Ibrahim, A. M. H., HuertaEspino, J., Calvo-Salazar, V., and Rudd, J. C. 2013. Genetic analysis of adult plant resistance to yellow rust and leaf rust in common spring wheat Quaiu 3. Plant Dis. 97:728-736.

Cabral, A. L., and Park, R. F. 2014. Seedling resistance to Puccinia coronata f. sp. avenae in Avena stigosa, A. barbata and A. sativa. Euphytica 196:385-395.

Cabral, A. L., Singh, D., and Park, R. F. 2011. Identification and genetic characterisation of adult plant resistance to crown rust in diploid and tetraploid accessions of Avena. Ann. Appl. Biol. 159:220-228.

Carson, M. L. 2009. Broad-spectrum resistance to crown rust, Puccinia coronata f. sp. avenae, in accessions of the tetraploid slender oat, Avena barbata. Plant Dis. 93:363-366.

Carson, M. L. 2011. Virulence in oat crown rust (Puccinia coronata f. sp. avenae) in the United States from 2006 through 2009. Plant Dis. 95:1528-1534.

Chong, J., and Kolmer, J. A. 1993. Virulence dynamics and phenotypic diversity of Puccinia coronata f. sp. avenae in Canada from 1974 to 1990. Can. J. Bot. 71: 248-255. 
Chong, J., Leonard, K. L., and Salmeron, J. J. 2000. A North American system of nomenclature for Puccinia coronata f. sp. avenae. Plant Dis. 84:580-585.

Dyck, P. L., Samborski, D. J., and Anderson, R. G. 1966. Inheritance of adult-plant leaf rust resistance derived from the common wheat varieties Exchange and Frontana. Can. J. Genet. Cytol. 8:665-671.

Ellis, J. G., Lagudah, E. S., Spielmeyer, W., and Dodds, P. N. 2014. The past, present and future of breeding rust resistant wheat. Front. Plant Sci. 5:641.

Hegarty, M. J., Barker, G. L., Brennan, A. C., Edwards, K. J., Abbott, R. J., and Hiscock, S. J. 2008. Changes to gene expression associated with hybrid speciation in plants: Further insights from transcriptomic studies in Senecio. Philos. Trans. R. Soc. B 363:3055-3069.

Jellen, E. N., and Leggett, J. M. 2006. Cytogenetic manipulation in oat improvement. Pages 199-231 in: Genetic Resources, Chromosome Engineering, and Crop Improvement, Cereals, Vol. 2. R. J. Singh and P. P. Jauhar, eds. CRC Taylor \& Francis Press, Boca Raton, FL.

Klos, K., Admassu-Yimer, B., Babiker, E. M., Beattie, A. D., Bonman, J. M., Carson, M. L., Harrison, S. A., Ibrahim, A. M. H., Kolb, F. L., McCartney, C. A., McMullen, M., Mitchell-Fetch, J., Mohammadi, M., Murphy, J. P., and Tinker, N. A. 2017. Genome-wide association mapping of crown rust resistance in oat elite germplasm. Plant Genome 10.

Leonard, K. J., Anikster, Y., and Manisterski, J. 2004. Patterns of virulence in natural populations of Puccinia coronata on wild oat in Israel and in agricultural populations on cultivated oat in the United States. Phytopathology 94:505-514.

Leonard, K. J., and Martinelli, J. A. 2005. Virulence of oat crown rust in Brazil and Uruguay. Plant Dis. 89:802-808.

Lin, Y., Gnanesh, B. N., Chong, J., Chen, G., Beattie, A. D., Mitchell Fetch, J. W., Kutcher, H. R., Eckstein, P. E., Menzies, J. G., Jackson, E. W., and McCartney, C. A. 2014. A major quantitative trait locus conferring adult plant partial resistance to crown rust in oat. BMC Plant Biol. 14:250.

McCallum, B. D., Fetch, T., and Chong, J. 2007. Cereal rust control in Canada. Aust. J. Agric. Res. 58:639-647.

McCartney, C. A., Stonehouse, R. G., Rossnagel, B. G., Eckstein, P. E., Scoles, G. J., Zatorski, T., Beattie, A. D., and Chong, J. 2011. Mapping of the oat crown rust resistance gene $P c 91$. Theor. Appl. Genet. 122:317-325.

McIntosh, R. A., Wellings, C. R., and Park, R. F. 1995. Wheat Rusts-An Atlas of Resistance Genes. CSIRO Publishing, Collingwood, VIC, Australia.
McMullen, M. S., Doehlert, D. C., and Miller, J. D. 2005. Registration of 'Hifi' oat. Crop Sci. 45:1664.

Milus, E. A., Moon, D. E., Lee, K. D., and Mason, R. E. 2015. Race-specific adultplant resistance in winter wheat to stripe rust and characterization of pathogen virulence patterns. Phytopathology 105:1114-1122.

Peterson, R. F., Campbell, A. B., and Hannah, A. E. 1948. A diagrammatic scale for estimating rust intensity of leaves and stem of cereals. Can. J. Res. Sect. C. 26c:496-500.

Portyanko, V. A., Chen, G., Rines, H. W., Phillips, R. L., Leonard, K. J., Ochoki, G. E., and Stuthman, D. D. 2005. Quantitative trait loci for partial resistance to crown rust, Puccinia coronata, in cultivated oat, Avena sativa L. Theor. Appl. Genet. 111:313-324.

Rines, H. W., Porter, H. L., Carson, M. L., and Ochocki, G. E. 2007. Introgression of crown rust resistance from diploid oat Avena strigosa into hexaploid cultivated oat $A$. sativa by two methods: Direct crosses and through an initial $2 x .4 x$ synthetic hexaploid. Euphytica 158:67-79.

Sandhu, K. S., Singh, D., and Park, R. F. 2014. Characterizing seedling and adult plant resistance to Puccinia hordei in Hordeum vulgare. Ann. Appl. Biol. 165: 117-129.

SAS Institute. 2014. SAS Enterprise Guide v. 7.1 for Windows. SAS Institute, Inc. Cary, NC.

Simons, M. D. 1985. Crown rust. Pages 131-172 in: The Cereal Rusts: Diseases, Distribution, Epidemiology, and Control. A. P. Roelfs and R. Bushnell, eds. Academic Press, Orlando, FL.

Simons, M. D., Martens, J. W., McKenzie, R. I. H., Nishiyama, I., Sadanaga, K. Sebesta, J., and Thomas, H. 1978. Oats: A Standardized System of Nomenclature for Genes and Chromosomes and Catalogue of Genes Governing Characters U. S. Dep. Agric. Handb. No. 509. U.S. Government Printing Office, Washington, DC.

Sowa, S., Paczos-Grzeda, E., Koroluk, A., Okon, S., Ostrowska, A., Ociepa, T. Chzastek, M., and Kowalczyk, K. 2016. Resistance to Puccinia coronata f. sp. avenae in Avena magna, A. murphyi, and A. insularis. Plant Dis. 100:1184-1191.

Stubbs, R. W., Prescott, J. M., Saari, E. E., and Dubin, H. J. 1986. Cereal Disease Methodology Manual. CIMMYT, Mexico.

Tan, M. Y. A., and Carson, M. L. 2013. Screening wild oat accessions from Morocco for resistance to Puccinia coronata. Plant Dis. 97:1544-1548. 